\title{
The Political Economy of Bilateral Foreign Aid
}

\section{Citation}

Werker, Eric D. "The Political Economy of Bilateral Foreign Aid." Harvard Business School Working Paper, No. 13-026, September 2012.

\section{Permanent link}

http://nrs.harvard.edu/urn-3:HUL.InstRepos:9556366

\section{Terms of Use}

This article was downloaded from Harvard University's DASH repository, and is made available under the terms and conditions applicable to Open Access Policy Articles, as set forth at http:// nrs.harvard.edu/urn-3:HUL.InstRepos:dash.current.terms-of-use\#OAP

\section{Share Your Story}

The Harvard community has made this article openly available.

Please share how this access benefits you. Submit a story.

Accessibility 


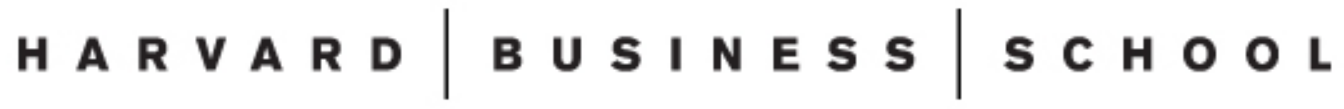

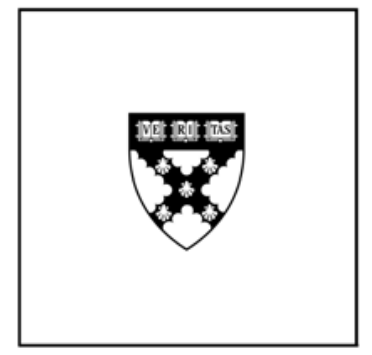

\title{
The Political Economy of Bilateral Foreign Aid
}

\author{
Eric Werker
}

\section{Working Paper}

13-026

September 5, 2012 


\title{
The Political Economy of Bilateral Foreign Aid
}

\author{
Eric Werker \\ Harvard Business School
}

September 5, 2012

\begin{abstract}
Despite its developmental justification, aid is deeply political. This paper examines the political economy of aid allocation first from the perspective of the donor country, and then the political economy of aid receipt and implementation from the perspective of the recipient country. When helpful, it draws from studies of multilateral aid. Following those discussions, the paper explores solutions, employed by the development community, to the distortions brought about by the political economy of bilateral aid - distortions that steer aid away from achieving economic development in the recipient country. As it turns out, none of these solutions can shield foreign aid from the heavy hand of politics. Developing countries heavily influenced by foreign aid end up with a different, and novel, governing apparatus.
\end{abstract}


Kyrgyzstan is a landlocked, mountainous nation of five million people bordering three other landlocked former Soviet states and the remote Chinese province of Xinjiang. With the fall of the Soviet Union, Kyrgyzstan's production fell significantly, sending the economy back a generation to animal herding and cotton growing. Since the attacks of September 11, 2001, in the United States, however, there has been a new foreign-exchange earner, stemming from RussoAmerican competition over the use of an airfield - and the very allegiance of Kyrgyzstan itself. In preparation for its campaign in Afghanistan, the United States secured access to air fields in Kyrgyzstan and neighboring Uzbekistan with a mixture of foreign aid and infrastructure upgrading. However, in 2005, the United States was kicked out by the Uzbeks for criticizing a government-led massacre (Walsh, 2005; The Guardian), and the following year a new Kyrgyz government argued that the base contracts had disproportionately benefited cronies of the old regime. They demanded a 100-fold increase in "rent" from the base, to \$200 million (Cooley, 2009; The New York Times).

The Americans were able to maintain Kyrgyz air access for the Afghanistan campaign through a $\$ 150$ million aid package, including \$18 million in rent. This uneasy balance remained for a few years, with U.S. support buying access to the air base. Meanwhile, with global commodity prices rising, a cash-rich Russia began to reassert its influence in what had historically been its backyard. While on a visit to Moscow in early 2009, the Kyrgyz president announced that the Americans had 180 days to vacate the base. Russia had offered Kyrgyzstan a $\$ 300$ million loan for economic development, a \$150 million grant for budget stabilization (it was the financial crisis), and forgiveness of most of the $\$ 180$ million in debt that the Kyrgyz state owed Russia (Nichol, 2009). After extensive negotiations, the United States managed to keep air access to Kyrgyzstan, but not before raising the rent on the base and offering additional support for economic development, counternarcotics, and counterterrorist programs.

Foreign aid has always been political. This fact has come as no surprise to scholars and practitioners of statecraft. Describing one of the functions of aid, Hans Morgenthau, one of the founders of realist international relations theory, noted: "the transfer of money and services from one government to another performs here the function of a price paid for political services rendered or to be rendered" (1962, p. 302). Indeed, since the late 1940s, every U.S. administration considered foreign aid to be important in achieving foreign policy goals (Ruttan, 1996). 
The "political services" Morganthau referred to are not usually as blatant as the case of the Kyrgyz air base. While episodes of discrete political quid pro quos abound in aid, more frequently, the donor nation is attempting to realize a broader ambition. Donor nations may give aid in order to further their economic interests, from the assistance of their companies' commercial ventures to a larger pursuit of trade and market access. Donors may seek to achieve far-reaching political goals like support on international initiatives undertaken by the donor nation. Indeed, donors may even offer assistance to realize the "values" of their electorates to be good global citizens. Aid is, for the most part, a normal good, and the list of aid donors has grown just as the number of nations with global interests and an effective source of revenue has increased.

Even as aid disbursement is driven by political goals in the donor countries, these goals frequently coincide with the needs of populations in recipient countries. For a variety of reasons, most donors now view the reduction of poverty and suffering in far-flung countries as consistent with their national interest. Whether from an ethos of responsibility or a calculated decision to reduce terrorist activity, multiple political justifications currently align most donor countries around a common development and humanitarian agenda. But that has not freed aid from political interference. Moreover, the second that foreign aid crosses the border, the receipt and disbursement of funds becomes intertwined with domestic politics in the recipient country.

As part of its attempt to explore the political economy of bilateral foreign aid, this chapter examines the politics of aid allocation from the perspective of the donor country, and then the politics of aid receipt and implementation from the perspective of the recipient country. When helpful, it draws from studies of multilateral aid. Following those discussions, the chapter explores solutions, employed by the development community, to the distortions brought about by the political economy of bilateral aid - distortions that steer aid away from achieving economic development in the recipient country. As it turns out, none of these solutions can shield foreign aid from the heavy hand of politics.

\section{Political Economy of Aid Disbursement}

Nearly all donor nations give aid through at least two channels: a bilateral aid agency that answers directly to the country's government and multilateral agencies such as the World Bank. 
Countries typically have less control over multilateral aid allocation, though multilateral agencies are able to share the fixed costs of operating a development agency with sector specialists and various disbursement locations. (In many cases, national governments have quite a bit of control over their donations through multilateral agencies, which often allow them the ability to earmark aid dollars for specific projects in specific countries. Yet the coexistence of bilateral agencies and multilateral ones for nearly every donor suggests that bilateral agencies allow a level of control over the aid not available when working through development banks.)

Looking around OECD capitals, one would question whether Morgenthau had been completely mistaken. According to Britain's Department for International Development (DFID), "The UK government believes it is in all our interests to help poor people build a better life for themselves." The Danish Ministry of Foreign affairs states that "Poverty reduction remains the fundamental challenge for Danish development cooperation,"2 while the Norwegian Agency for Development Cooperation states that its aid should be administered in such a way that it "contributes effectively to poverty reduction."3 U.S. foreign assistance has the purpose of "expanding democracy and free markets while improving the lives of the citizens of the developing world."4 Many bilateral agencies recognize that they are pursuing foreign policy interests at the same time but never that they are buying anything resembling Morganthau's "political services."

Yet when Alesina and Dollar (2000) set out to determine whether aid flows corresponded to politics or need, they found that political variables explained "a large, but not exclusive extent" of cross-country differences (34). In particular, measures of former colonial status, voting in the United Nations, and being Israel or Egypt were far better predictors of foreign aid receipt than income per capita, trade policy, or democratization. How to explain the apparent disconnect between Alesina and Dollar's results and the development rhetoric?

\section{With a little help from my friends}

\footnotetext{
1 "Who we are and what we do," DFID website: http://www.dfid.gov.uk/About-DFID/Quick-guide-to-DFID/Whowe-are-and-what-we-do/, accessed 04/12/10.

2 "Danish Development Policy," Ministry of Foreign Affairs website: http://www.um.dk/en/menu/DevelopmentPolicy/DanishDevelopmentPolicy/, accessed 04/12/10.

3 “About Norad," NORAD website: http://www.norad.no/en/About+Norad/About+Norad.125317.cms?show=all, accessed 04/12/10.

4 “This is USAID," USAID website: http://www.usaid.gov/about_usaid/, accessed 04/12/10.
} 
A look back to one of the most highly regarded episodes of aid, the Marshall Plan, offers some clues. The Marshall Plan involved around \$13 billion in aid (around 5 percent of US gross domestic product at the time) in mostly foreign exchange loans for Europeans to purchase critical imports, often from the United States. But, the aid was not merely humanitarian or a narrow stimulus to U.S. producers. The Americans, in providing aid to Europe, were rebuilding the very legs of the international economic system. As George Marshall said at Harvard University when introducing the policy:

[T] he consequences to the economy of the United States should be apparent to all. It is logical that the United States should do whatever it is able to do to assist in the return of normal economic health in the world, without which there can be no political stability and no assured peace... Its purpose should be the revival of a working economy in the world so as to permit the emergence of political and social conditions in which free institutions can exist. (Marshall, 1947)

American industry needed a market. Moreover, economic interdependence would help reduce the risk of conflict that had hung over the interwar period like a storm cloud.

The recipients of Marshall Plan aid would not have corresponded perfectly to the "political” variables in Alesina and Dollar's analysis. After all, while the Western Europeans may have had similar views on global political debates, this was by no means secure, as the precarious balances in Greece, Turkey, and Italy attested. The United States had no former colonies in Europe; in fact they gave aid to their former colonizer. Yet, to a student of history (e.g., Kunz, 1997), this aid was as political as any that had been used to sway a vote in the United Nations General Assembly. And its goal was the economic development of the recipient countries.

A similar project occurred during the Cold War, except instead of the shattered pieces of the global economy being reassembled and redirected, foreign aid was used as part of a new but slow-moving political competition. Aid was employed by both the Soviets and the Americans (as well as their allies) to affect the balance of power and the depth of allegiance to one governing system or another. They did not simply spend money to change governments or their preferences, although that certainly happened (Faye and Niehaus, 2010). Aid was also spent to improve the economic capacities of one's allies. In Vietnam, for example, the Soviets built massive hydroelectric facilities, while in South Korea, the Americans funded schools and land 
improvement. In this game of chess or dominoes, it was not just the number of pieces one had on the board, but their strength as well.

Today, the closest thing to the Marshall Plan is also inherently political to the donor country and developmental in its aims. The largely Anglo-American global "war on terror" led to a reorientation of development with security, completing the vision, observed by Jude Howell, of "an emerging view of the South as a source of international crime, terrorism and conflict that contributed to global instability" (2006, p. 123). The development policy resulting from such a world view includes a heavy emphasis on reducing the incidence of so-called failed states, as well as eliminating the economic situations that benefit terrorist recruitment. (These policies have continued to be enthusiastically pursued in spite of careful microeconomic evidence that finds that terrorists are neither poor nor poorly educated (Krueger, 2007).) The take-home message, of course, is the same: a vast amount of aid dollars are spent in order to improve the perceived security of the donor countries' populations.

\section{Empirically speaking}

The vast majority of recent empirical papers on the determinants of aid have sought to make the case that much of aid allocation is politically motivated. What motivates one donor, however, may not motivate another. In one analysis, Schraeder et al. (1998) find that, on balance, Japanese aid is motivated by economic and trade interests, Swedish aid supports progressive, socialist-minded regimes, while France's aid is almost exclusively targeted towards francophone countries. Neumeyer (2003) finds that OPEC donors, including Saudi Arabia, Kuwait, and United Arab Emirates, favor other Arab and non-Arab Muslim recipients. This not insubstantial literature has forcibly established that, across the global sample of recipient countries, so-called economic or humanitarian variables are insufficient to explain the direction and quantity of aid donations. Instead, variables that correlate with connections to, or interest of, the donor country seem to explain a great quantity of aid flows. However, what most of this literature fails to argue convincingly is that the political motivations behind aid imply that developmental motivations are absent, or that politically motivated aid is any less successful in reducing poverty.

As the Marshall Plan, the war on terror, and even the Cold War demonstrate, just because aid may be designed to benefit the donor country, it does not easily follow that it is any less developmentally motivated. (In fact, one could make the case that donors would be more 
effective when their self-interest is served by the progress of the recipient country.) Giving more to one's allies than one's enemies, or more to one's trading partners than to countries with no common economic interests, seems benign, if not thoughtful. Yet, in Kyrgyzstan, the US aid seemed to be designed to secure nothing more than Air Force access, and after the Russians bumped up the price of that access, the Americans were forced to award lucrative procurement contracts to cronies of Kyrgyz President Bakiyev (Koring, 2010). When Bakiyev was overthrown in a violent coup, the outcome could hardly be described as developmental.

Accounts of aid being used for strictly political ends of the donor country - with no corresponding developmental aims for the recipient country-like in Kyrgyzstan have been reported in isolation. Economists seeking to determine whether these anecdotes are indicative of broader trends have run into the challenge noted earlier: there are rare cases in which political variables determining aid flows have no corresponding story in which the donor wants the recipient to succeed.

One exception is a paper by Kuziemko and Werker (2006) that examines aid to nonpermanent members of the U.N. Security Council. The Security Council has arguably been the world's most important committee, with the power to authorize multilateral sanctions and military action. As 10 of the 15 seats on the Security Council are held for a nonrenewable 2-year term, when a nation enters the Council, it experiences a temporary increase in its political value to donor nations. Membership led to an increase in US and UN foreign aid-particularly in years in which the Council discussed matters of high importance - that disappeared once the country was no longer serving. Like recent aid to the Kyrgyz government, this practice appears to have little to do with promoting development. What fraction of foreign aid is politically motivated, without any intention to promote development, is still an open question. In all likelihood, that number today may be quite small.

\section{Does it matter that aid allocation is political?}

Beyond the case that the political economy of aid may occasionally result in "assistance" flowing to the donor, there exists a suspicion that politically motivated aid is somehow less effective than aid given through pure altruism. Alesina and Dollar (2000), for example, conclude from their analysis identifying political aid flows that the allocation of aid "provides evidence as to why it is not more effective at promoting growth and poverty reduction." Others come to the 
same conclusion. As it turns out, it is not easy to test whether politically motivated aid does not work as well: most settings in which the donor has a political motivation are also indicative of an omitted-variable bias when testing for the effectiveness of the aid. For example, Cold War allies of the United States may have been more likely to face a military or socialist threat, which would certainly affect the likelihood an aid project would succeed or fail. Countries with similar voting records in the United Nations might be the sorts of places where one's aid technocrats had the most success in helping out. In other words, it is hard to find natural variation in the amount of politically motivated aid that is not correlated with its underlying potential effectiveness.

In one example, Werker et al. (2009) examine the economic impact of politically motivated foreign aid donated by Arab oil producers. Donors such as Saudi Arabia and Kuwait have been among the World's most generous, giving over $1.5 \%$ of their GDP (Neumayer, 2003). Although some of this money did go to famines and other disasters around the world, the vast majority went to other Muslim nations. No doubt the motivation for this was largely political: the Gulf countries were trying to quell unrest due to the huge inequality among their coreligionists (between the oil haves and have-nots), as well as to "assure them[selves] a clear position of dominance within the Muslim world" (Kepel, 2002, pp. 69-70).

What makes the Arab aid amenable to further analysis is its extraordinary timing. Donations from the Gulf oil producers essentially tracked movements in the price of oil. Their foreign aid programs only began in earnest with the oil crisis of 1973, picked up steam through the oil crisis of 1979, and fell off abruptly as oil markets flooded in the early 1980s. This allows for a difference-in-differences analysis, comparing (nonoil-producing) Muslim aid recipients with non-Muslim countries that are similar in other respects. The analysis found no significant effects on economic growth, yet large increases in imports-especially noncapital goods, consumption, and even investment. How does this compare to nonpolitical aid? Estimates of the growth effects of aid that is not politically motivated are actually quite hard to identify, due to the methodological challenges of finding a suitable instrument (Roodman, 2007).

While the Gulf aid was politically motivated, it very likely had a developmental component as well. The determination of the impact of foreign aid flows that are politically motivated yet with no plausible development component has proven even harder. The first challenge, as noted earlier, is that it is hard to systematically isolate this type of aid. The second challenge is that outcome measures like economic growth are very noisy, not to mention those 
caused by a number of factors other than aid itself. One recent attempt by Dreher et al. (2010) attempts to measure the effectiveness of aid going to nonpermanent members of the UN Security Council. On account of the noisiness of economic growth as an outcome, the paper focuses on effectiveness ratings attached to World Bank projects by their own evaluation team. Although World Bank aid is not bilateral, the findings provide some context to scholars of bilateral aid. Surprisingly, the authors found little reduction in project effectiveness ratings when they were awarded to Security Council members - unless those countries were economically mismanaged at the time of award.

On the whole, the economics research on the political economy of bilateral foreign aid has shown quite conclusively that aid is allocated according to political interests. This corresponds to accounts of aid disbursement by diplomats as well as by journalists and scholars in other fields. Where the research has been less conclusive is in making the case that politically motivated aid has no developmental component, and that such aid is any less effective than aid given for purely altruistic or humanitarian reasons. Part of this lack of conclusiveness in the research on the political economy of foreign aid is no doubt driven by the difficulty of a foreign actor improving the economic situation of another country, and part by the more mundane empirical challenges of measuring aid effectiveness.

\section{Political Economy of Aid Receipt}

Once aid has been disbursed to a recipient country, it is by no means free of political economy challenges. When foreign aid enters the recipient country, it enters a political system far more complex than the foreign-affairs networks in the donor countries that spawned it. In this domestic context, foreign aid can increase the conflict over scarce governmental resources, it can shift the competitive balance across sectors of the economy, and it can change the very relationships the government has with its opposition and its citizens.

\section{Capital to the capitol}

One of the most basic effects of aid is to increase the size of the governmental "pie," and if there are multiple groups dividing the pie, aid can lead to increased fighting over it (Grossman, 1992). This is an example of Tornell and Lane's "voracity effect" (1999), in which a positive 
shock perversely reduces growth in an economy with weak institutions due to a more than proportionate increase in fiscal redistribution. Svensson (2000) articulates this in a paper on foreign aid and rent-seeking where he constructs a repeated game with stochastic shocks, where the increase in rent-seeking behavior results from a failure of coordination across the interest groups. This is not simply a theoretical construct. At its most extreme-when aid is one of the few sources of hard currency in the country - there can be very deliberate fighting over foreign assistance. During the barren war in Somalia in the 1990s, when the government and the economy were all but destroyed, shipments of humanitarian aid were quite frequently the objects over which militias fought (Peterson, 2000). When the situation is more subtle, aid can still lead to more conflict at the margin: increasing the return to a coup d'état, for example, or luring more actors into the political space.

While aid can increase the size of the pie, thus leading to a generic increase in conflict, it can also affect the political sphere in a more predictable manner. Most aid will tend to reinforce existing power structures since it is disbursed through, or in consultation with, governmental actors. Examining decades of aid in pre-genocide Rwanda, Uvin (1998) describes a systematic but largely unintentional favoring of the Rwandan Tutsi. He argues that the development aid in pregenocide Rwanda contributed to and exacerbated the structural differences between the Hutu and the Tutsi, reinforcing the conditions that eventually led to violence.

Even today, "responsible" donors are supposed to help the government of the day. Governments put together a poverty reduction strategy paper (PRSP) that, according to the World Bank, "sets out a country's macroeconomic, structural, and social policies and programs to promote growth and reduce poverty, as well as associated external financing needs." are expected to fund projects that are part of the government's PRSP. (Of course, this may simply set off another round of strategic behavior between the government and its citizens, in which voters in aid-dependent developing countries evaluate their leaders not only on observed public spending, but on their manipulation of the donors.) Aid has been criticized of keeping bad regimes in power (Moyo, 2009).

However, not all political actors benefit equally from foreign aid. During the Cold War, aid was used very deliberately to affect internal politics - promoting allies at the expense of

\footnotetext{
5 "What are PRSPs?" World Bank website: http://web.worldbank.org/WBSITE/EXTERNAL/TOPICS/EXTPOVERTY/EXTPRS/0,,contentMDK:22283891 pa gePK:210058 piPK:210062 theSitePK:384201,00.html, accessed Apr 14, 2010.
} 
potential adversaries, whether in Italy or Congo (Devlin, 2007; Miller, 1983). Analyzing aid patterns around elections in the recipient countries, Faye and Niehaus (2010) found that administrations that were politically aligned with a donor received more aid during close elections. Similarly, the United States gave more aid to nongovernmental entities during election years in which the administration was not aligned. Even today, aid officials quite deliberately try to work with the "reformers within the government so that their preferred projects will have the best chance of working." Nelson (2009) finds that International Monetary Fund loans are larger and more forgiving when they are granted to countries with "neoliberal" policymakers who are defined as those who have earned at least a Master's degree at a top US economics department, or who have experience working at the Bank or at the Fund. In Sierra Leone's conflict resolution and postconflict development, the more successful interventions have involved building deliberate coalitions between donors and political actors in the recipient country who are the natural allies of reform (Thomson, 2007).

\section{Spending hard-earned aid}

Recipients, for their part, use the aid strategically. Governments regularly attempt to direct infrastructure projects towards the regions with the highest political return and to use donor-funded budgetary support in order to pay government workers, many of whom are part of the government's patronage network. A number of the aid projects that have been proposed by recipients of the U.S. government's Millennium Challenge Account funds, which asks the recipient country for a "wish list" of major projects, include very targeted regional requests. ${ }^{6}$ In China, Zhang (2004) found that Chinese political and bureaucratic interests did a far better job of explaining World Bank project allocation at the provincial level than did humanitarian or economic variables. For example, coastal provinces would have more likely got Bank projects in the 1980s when government priorities were aimed at developing the East; however, when the government shifted in the late 1990s to focus state-led development efforts on the interior provinces, the coastal provinces received less in Bank financing. (Governments also block aid strategically. The Ethiopian government in the 1980s and the Sudanese government, in much of its regional conflicts, regularly blocked basic relief aid to areas with opposition support (Kaplan,

\footnotetext{
${ }^{6}$ Project descriptions are posted clearly on www.mcc.gov.
} 
2003; Perlez, 1990).) The net result of the strategic political behavior on the part of the recipient government is to increase their power and control.

Yet not all "unearned" resources are good for the government and its relationship with its constituencies. Much of the literature on the so-called resource curse follows the traditions in history and institutional economics that sees the evolution of the state as the result of bargaining between revenue-maximizing leaders and their citizens (e.g. North and Weingast, 1989; Tilly, 1992). In a nutshell, rentier state literature (e.g. Mahdavy, 1970) discusses the ramifications for mostly oil-producing countries that derive their income from the sale of a commodity as opposed to through a tax base. The political bargains that these states make with their citizens center on the distribution of largesse in exchange for staying in power, as opposed to ceding influence over policy choice in exchange for taxes.

Moore (1998) applies rentier state arguments to foreign aid. He argues that the greater the dependence of state income on unearned income, the less likely that state/society relations are to be "characterized by accountability, responsiveness, and democracy" (85). In other words, when governments do not need to collect taxes from their citizens because they are being financed by foreign aid, likewise they may not be pressured to respond to the needs of their citizens to the same degree. Through this channel, foreign aid reduces the responsiveness of governments to their citizens and leads to governments choosing policies that their citizens would not necessarily choose-or at least those citizens not lucky enough to be in government patronage networks.

Like CEOs who may not govern fully in the interest of the firm's shareholders, leaders of aid-rich nations may seek to capture government resources for their private benefit. The list of corrupt governments that receive substantial amounts of aid is certainly long, from Karzai's Afghanistan (New York Times, 2010) to Mobuto's Zaire (Transparency International, 2004). Alesina and Weder (2002) examine whether less corrupt governments are rewarded with increased aid. They find that more corrupt countries receive, if anything, larger amounts of aid. But we could ascribe this to political-economy channels in aid allocation, as donors used aid to further their foreign-policy goals. Whether aid corrupts recipient country governments is a different matter. Here the evidence is inconclusive, no doubt complicated by the challenges of arguing causality. Svensson (2000) and Alesina and Weder (2002) argue that the data show a possible increase in corruption from foreign aid, while Tavares (2003) finds that aid reduces 
corruption. This points to the sensitivity of the results to different methods of managing the inherent endogeneity in the data.

\section{It's the economy, stupid}

Foreign aid can also affect the political economy of the recipient country through economic channels. One of the primary channels echoes the natural resource problem, just as it does via political channels. Just as natural resources can lead to "Dutch disease" through currency appreciation, so too can the capital inflows associated with the unearned income of foreign aid lead to a rise in the real exchange rate. In Dutch disease, the demand for local goods and services associated with a boom in the natural resource sector (or aid projects, in this case) raises the real exchange rate, which harms the competitiveness of the manufacturing sector, since it competes with the aid sector for inputs. There is no shortage of descriptions of aid booms that drive up factor prices in the economy. In postwar Mozambique, for example, the price movements were evident to a contemporary observer:

Donors buy up the best people - most engineers will not work for the government for $\$ 100$ a month when they can earn 20 times that much working for a donor. Mozambique now has about 3,000 foreign aid workers employed by the United Nations, World Bank, bilateral donors and non-government organizations. Often they simply fill gaps caused by other donors having hired Mozambican technicians at high salaries... The streets of the capital, Maputo, are full of new luxury four-wheel-drive vehicles. There is a building boom of expensive houses. (Hanlon, 1996)

But when countries have a vast pool of labor and land, can aid significantly affect prices that the productive sectors actually face?

Rajan and Subramanian (2010) pool data on foreign aid and growth in manufacturing and find evidence suggesting that Dutch disease is prevalent in aid more generally. Their analysis finds that when countries have received more in foreign aid, the "exportable" sectors of the economy experience slower growth. This reduced performance appears to be driven by an increase in the real exchange rate. How is this seemingly abstruse economic effect political? For one, if manufacturers once commanded extensive political power, the gradual erosion of their competitiveness could reduce their control over political outcomes. Second, it could generate new power brokers, as construction magnates and property owners (not to mention politicians 
themselves) become the new titans. A critical analysis of the Mozambique boom, for example, found that the prime beneficiaries were "large Mozambican trading companies, a new Mozambican aid and comprador group, white South Africans and foreign companies" (Hanlon, 1996). These changes could have nonrandom effects on longer term economic and political development, given a possibly vital role of the tradable sector (Rodrik, 2008).

Foreign aid, then, can enter and change the political equilibrium of the recipient country when it constitutes a large resource flow. Unlike in aid disbursement, the political economy effects of aid receipt are invasive, and the challenges affect the recipient population at all levels. That said, donors can also be a force for positive political change, when they target their aid to reformers within the country, and when they provide positive incentives that outweigh the negative effects of aid on the political climate.

\section{Making Good}

It is not particularly insightful to say that aid is political, since political forces are behind why aid was developed and why it continues to survive. However, the political economy of aid allocation and receipt does interfere with its optimal distribution from a developmental standpoint. Aid policymakers, seeking to maximize the developmental impact of foreign assistance, have devised a number of ways to attempt to subvert the political forces at work. Morganthau, on the other side of the coin, believed that the developmental aims of aid interfered with its political functions. Of the aid that is truly political, Morganthau observed that:

Bribery disguised as foreign aid for economic development makes of giver and recipient actors in a play which in the end they may no longer be able to distinguish from reality. In consequence, both may come to expect results in terms of economic development which in the nature of things may not be forthcoming. $(1962,303)$

That critique is worth keeping in mind as we examine the efforts to depoliticize aid allocation and spending.

\section{Taking the politics out of aid allocation}


Politicians have managed, in many cases, to fix politically driven inflationary monetary policy by making independent central banks with clear missions. Looking at the field of foreign aid, one would see institutions such as the World Bank or the regional development banks (African, Asian, Inter-American, and European) and believe that they might be a corollary to independent central banks. After all, the World Bank is not beholden to any one government; its staff enjoy diplomatic privileges and are chosen based on their commitment to development; and the mission of the World Bank is to "fight poverty" and "help people help themselves." What about this isn't independent?

For starters, its management structure is not politically neutral. The Bank is overseen by an executive board composed of representatives from member-state governments, both donors and recipients. It is run by an American president. (The Europeans get to run the IMF.) This direct supervision provides incentives for governments to meddle with the lending decisions of the Bank. Kaja and Werker (2010) investigate whether the executive board, which is made up of only 24 members, receives special privileges. As it turns out, developing countries on the board can expect to receive approximately double the loans from the International Bank for Reconstruction and Development, the largest of the World Bank's divisions. So, one downside of trying to insulate donor politics from aid allocation decisions is that the recipients themselves can try to capture the agenda.

But donors, in fact, do a very poor job of stepping back from aid allocation decisions made at international financial institutions. Lending at the World Bank's low-income-targeted International Development Association is correlated with US political interests as measured by UN voting on important issues (Andersen et al., 2006). The big decisions at the IMF are controlled by the G7 (Fratianni and Pattison, 2005) and the United States in particular (Woods, 2003), and loans are larger and more frequent to US allies (Barro and Lee, 2005). Indeed, both IMF and World Bank loans increase to countries when they become nonpermanent members of the UN Security Council, suggesting a complex system of global horse-trading between votes at the Security Council by developing countries and aid decisions by the donors through the Bank and the Fund (Dreher et al., 2009a,b). In some situations, donor governments even prefer

\footnotetext{
7 “About Us." World Bank website: http://web.worldbank.org/WBSITE/EXTERNAL/EXTABOUTUS/0,,contentMDK:20040565 menuPK:1696892 pa gePK:51123644 piPK:329829 theSitePK:29708,00.html, accessed 14 Apr 2010.
} 
donating highly political aid through these institutions as it allows them to bypass their legislatures.

On the whole, then, multilateral aid institutions do not do a good job of insulating aid allocation decisions from politics. To be fair, this was never their intention in the first place. The structure of the development banks and the IMF was designed to ensure that their biggest funders had extensive oversight over the day-to-day operations.

Donor governments have had somewhat more success in designing institutions within the government and such institutions are mandated to put developmental needs on the front burner. Britain established a cabinet-level position and endowed the new DFID with broad responsibilities, not to mention a seat at the table voicing "development concerns" in larger discussions on foreign policy. DFID has since come to be recognized as the premier bilateral development agency by development commentators around the world (e.g., Richard and Rupp, 2009).

In the United States, the Millennium Challenge Corporation (MCC) was created in 2004 alongside the more established Agency for International Development. According to its charter legislation, the MCC gives aid to poor countries committed to "just and democratic governance... economic freedom... [and] investments in the people" based on "objective and quantifiable indicators." 8 In practice this has meant selecting countries by income category according to 17 published indicators, such as the advocacy nongovernmental organization (NGO) Freedom House's indicator on political rights. Income-eligible countries receive a score, and (in a slight oversimplification) those above the line are theoretically eligible, while those below the line are not. This system has been subverted on at least one occasion, granting a $\$ 295$ million aid package to Georgia — even as the country was below the bar on corruption and several other indicators (Phillips, 2006). Compared to the politics of other aid flows, however, such a transgression appears quite minor, and the fact that it brought so much negative attention is a testament to the relative success of the MCC.

Yet another way to insulate foreign aid allocation decisions from international and domestic politics goes relatively unnoticed. The tax laws of donor countries such as the United States allow for tax-deductible donations to NGOs, even as these entities may spend their charity

8 “Millennium Challenge Act of 2003." http://www.mcc.gov/mcc/bm.doc/mca_legislation.pdf, accessed April 15, 2010 . 
abroad. The foregone tax here is essentially a contribution of the donor government to the activities of the NGO abroad, those activities having been decided outside of government channels. (Governments fund NGOs abroad as well, often hiring them to implement foreign aid activities in the national interest, but NGOs are free to spend their privately-raised donations where they like.) Economists have examined whether NGO aid disbursement does any better at responding to humanitarian or developmental needs, rather than the political forces of the country in which they are based. Available accounts, using a similar methodology as Alesina and Dollar (2000), find mixed results on whether NGO aid disbursement is more correlated with humanitarian and developmental variables than is official foreign aid (e.g., Nancy and Yontcheva, 2006; et al., 2008). Moreover, utilizing a decentralized approach to development assistance, while having some advantages, introduces a new set of problems (Werker and Ahmed, 2008).

Immunizing foreign aid from donor-driven political economy distortions is by no means an easy task, nor has it been successfully accomplished through any particular institutional innovation.

\section{Saving aid from itself, or, taking the politics out of aid receipt and disbursement}

At the level of the recipient, there have been a number of institutional innovations to minimize the negative political economy from aid disbursement. Recall that some of the negative political economy effects were conflict over resources (including corruption), incumbency advantage (including geographic distribution of funds), insulation from citizenry through not having to raise revenue domestically, and the reduced competitiveness of the tradeable sector. Individually, these innovations may circumvent particular negative effects of aid on the recipient country's political economy. Collectively, however, their success is far less obvious.

To minimize the chance that aid will be siphoned off by corrupt officials, donors often set up so-called project implementation units (PIUs). These are essentially structures parallel to the recipient government with rigorous procurement, financial management, and reporting controls. By providing tighter seals around aid projects, PIUs can reduce the potential for aid to be captured by the domestic elite for their own benefits, and they are widely used for this purpose (Asian Development Bank, 2005). 
To reduce the incumbency advantage of the acting government, and to prevent the geographical targeting of aid for political reasons, aid agencies have sought to "decentralize" the provision of aid (e.g., USAID, 2000). Decentralization involves a combination of promoting subnational governance structures, local elections, and local management of natural resources. For the aid practitioner, it may mean offering technical assistance to state and local government or planning and funding development projects in collaboration with the local government. It may also involve lobbying for more local control over the rents from natural resource extraction. In this way, aid can respond more closely to the needs of the citizens than the political strategies of their national governments.

To increase the state-citizen obligations that may be reduced through foreign aid substituting for domestic taxation, aid agencies generally require extensive public consultation. To make sure that aid projects represent the desires of affected populations, aid agencies and the government entities they are working with hold a number of "consultative processes" along the way. These normally entail holding meetings in affected communities, running workshops with representatives of civil society, and participating in media campaigns. Through these activities, input can be gathered from those "stakeholders" who would be affected by the project, and ideally incorporated into the project planning.

Reducing the likelihood of Dutch disease from aid inflows is a challenging matter (IMF 2005). If aid involves a real transfer to the recipient country, it must involve an increase in net imports to the country. Those imports can, simplistically, either be spent directly on goods or services, or indirectly through increased market activity and incomes, which stimulates demand for imports from the population. When import increases occur through an increase in demand, most likely at the same time (or, indeed, as the driving factor) there will have been an increased demand for nontradables - resulting in a price increase. Such is the cause of Dutch disease. So if aid is spent directly on imports (i.e., it is given in kind), then it will have a smaller effect on the real exchange rate. Of course, depending on what is imported, such aid could still reduce the demand for domestically-produced manufactured goods.

Perhaps the most sweeping intervention by donors to control any undesired political economy effects of foreign aid is to impose any number of conditionalities on the aid. These may take the form of granting aid, loans, or debt relief to a recipient country only after it satisfies a number of conditions. Those conditions might be broadly reaching, such as the free-market 
"Washington consensus" policy recommendations favored by the structural adjustment programs, which reached their zenith in the 1980s. Or they might be more subtle, for example, requiring that the operations of a port be privatized before a loan is granted to refurbish the port. While structural adjustment programs are out of fashion, in favor of a "country ownership" approach (World Bank, 2005), the presence of some conditionalities on foreign aid is still nearly ubiquitous. (Enforcing conditionalities, and other interventions to fix the negative political effects of aid receipt, may also be affected by the politics of aid disbursement; Kilby (2009) finds that the conditionalities associated with World Bank aid to US allies are more laxly enforced.)

Thus, there are a host of strong, theoretically-grounded policies that can be implemented to reduce individual political economy distortions inside the recipient country. Aid can be granted, in large quantities, and disbursed without being stolen, in projects that help the "regular" people, even far from the capital. Yet consider them as a package: a host of independent-fromgovernment PIUs handling the money; an emphasis on subnational government; countless streams of donor-driven consultative processes; goods and services imported in kind; and requirements on how funds are spent. This portfolio of interventions to reduce the distortions of aid ends up with the potential to sideline the national government while creating a selfperpetuating, parallel, and big-spending government-by-donors. Of course, many countries that fit this description have also benefitted from consistent growth, a stable macroeconomy, and reduced poverty, especially since the mid 1990s. And the most competent leaders of lessdeveloped countries are able to navigate the ills and the fixes of aid politics better than the foreign-assistance bureaucrats themselves, using the funds as well as the associated restrictions to further their particular agenda. Whether the cure becomes worse than the disease is an open question, and much of the public debate on aid itself covers this question without being explicitly conscious of it.

\section{Conclusion}

In analyzing the political economy of bilateral foreign aid, this chapter has explored the distortions present in aid allocation and spending, as well as the available fixes. As a profession, we economists know best the effects of political forces in the donor country on the disbursement of aid. We have established that politics drive aid allocation decisions, and by how much. We 
have examined the potential fixes to bilateral politics driving aid decisions, and found that some of these fixes - most principally, the international financial institutions - come up short in insulating the aid process from donor-country politics.

That said, we should not be so quick to jump to the conclusion that aid-for-development is doomed. We have been less successful in showing that politically driven aid entails worse outcomes for the recipients. Most politically driven aid still has a major developmental quotient, particularly today when donors see a prosperous and democratic Third World in their national interest. Moreover, there are a number of fora in which aid given for developmental reasons $i s$ in the national interest, particularly as it reflects the values of the taxpayers in the donor country. With national interests and values aligned with aid-for-development, donors are better able to insulate their own aid from short-term political pressures. It is in the increasing incidence of these situations that will be the most successful counter to the Morganthau critique, of aid-fordevelopment being a mere play, staffed with B-team actors.

When it comes to the political economy of aid disbursement and spending in the recipient country, this chapter has argued that the potential negative effect of politics is much greater. Whereas the politics in aid allocation are consistent with the national interest of the donor at least, the politics in aid receipt are easily corruptive to the political equilibrium of the recipient country. Aid can disturb the balance, tipping the politics toward more conflict, more incumbency advantage, more strategic patronage networks, and away from manufactures. Economists understand these dynamics, but not as well as (and with much less attention than) the simpler and more benign politics of aid allocation.

For better or for worse, there are a number of fixes available to mitigate the political economy distortions of aid receipt and implementation. Unlike with aid allocation, these fixes are used extensively - because the developmentally focused actors, the aid bureaucrats (and not the politicians), now control the purse strings. At their worst, these fixes can render impotent the national government in recipient countries, and its role in creating a healthy polity_replacing the usual governance relations with a heavy-handed development industry governing by analysis and not by politics. At their best, the donor fixes may better identify the needs of the recipient populations and better devise and monitor programs in their interest, meanwhile training a responsible generation of policy makers in developing countries who will have the ethos and experience to become responsible and competent leaders. 


\section{References}

Alesina, Alberto and David Dollar. (2000) "Who gives aid to whom and why?" Journal of Economic Growth. 5 (1) 33-63.

Alesina, Alberto and Beatrice Weder. 2002. "Do Corrupt Governments Receive Less Foreign Aid?" American Economic Review 92(4): 1126-1137.

Andersen, T. B., H. Hansen, T. Markussen (2006): "US Politics and World Bank IDA-lending," Journal of Development Studies, 42(5), 772-794.

Asian Development Bank. 2005. "The Role of Project Implementation Units.” Operations Evaluation Department: ADB, April.

Barro, Robert J. and Jong-Wha Lee, 2005, IMF-Programs: Who Is Chosen and What are the Effects? Journal of Monetary Economics 52: 1245-1269.

Cooley, Alexander. 2009. "How the U.S. lost its Kyrgyzstan air base." The New York Times. Feb 10.

Devlin, Larry. 2007. Chief of Station, Congo: Fighting the Cold War in a Hot Zone. New York: Public Affairs.

Dreher, Axel, Jan-Egbert Sturm, and James Raymond Vreeland. 2009a. Development Aid and International Politics: Does membership on the UN Security Council influence World Bank decisions? Journal of Development Economics 88 (1):1-18.

Dreher, Axel, Jan-Egbert Sturm, and James Raymond Vreeland. 2009b. Global Horse Trading: IMF loans for votes in the United Nations Security Council. European Economic Review: doi:10.1016/j.euroecorev.2009.03.002.

Dreher, Axel, Stephan Klasen, James Vreeland, and Eric Werker. 2010. "The costs of favoritism: Is politically-driven aid less effective?" Courant Research Centre Discussion Papers. No. 26. March.

Faye, Michael and Paul Niehaus. 2010. "Political Aid Cycles." Mimeo: UCSD.

Fratianni, Michele and John Pattison, 2005, Who is Running the IMF: Critical Shareholders or the Staff? In: P. de Gijsel and H. Schenk (eds), Multidisciplinary Economics: The Birth of a New Economics Faculty in the Netherlands, Berlin: Springer, 279-292.

Grossman, H. I. (1992) “Foreign Aid and Insurrection.” Defence Economics. 3 (4), 275-288.

Hanlon, Joseph. 1996. "Strangling Mozambique: International Monetary Fund 'Stabilization' in the World's Poorest Country." Multinational Monitor 17 (7).

Howell, Jude. 2006. "The global war on terror, development, and civil society." Journal of International Development, 18 (1): 121-135.

IMF. 2005. "The Macroeconomics of Managing Increased Aid Inflows: Experiences of Low-Income Countries and Policy Implications.” IMF: Policy Development and Review Department. August.

Kaja, Ashwin and Eric Werker. 2010. "Corporate Governance at the World Bank and the Dilemma of Global Governance.” World Bank Economic Review, 24 (2).

Kaplan, Robert. 2003. Surrender or Starve: Travels in Ethiopia, Sudan, Somalia, and Eritrea. New York: Vintage.

Kepel, Gilles. (2002) Jihad: The Trail of Political Islam, trans. Anthony F. Roberts. Cambridge, MA: Harvard University Press.

Kilby, Christopher. 2009. The political economy of conditionality: An empirical analysis of World Bank loan disbursements. Journal of Development Economics 89 (1):51-61.

Koring, Paul. 2010. "Kyrgyzstani Government Ousted in Violent Uprising." The Globe and Mail. April 7. Krueger, Alan. 2007. What Makes a Terrorist: Economics and the Root of Terrorism. Princeton, NJ: Princeton University Press. 
Kunz, Diane. 1997. “The Marshall Plan Reconsidered.” Foreign Affairs. May/June: 162-170.

Kuziemko, Ilyana and Eric Werker. 2006. "How Much is a Seat on the U.N. Security Council Worth? Foreign Aid and Bribery at the United Nations." Journal of Political Economy.

Mahdavy, Hossein. (1970) "The Patterns and Problems of Economic Development in Rentier States:

The Case of Iran." In Studies in the Economic History of the Middle East from the Rise of Islam to the Present Day by M. A. Cook. Oxford: Oxford University Press.

Marshall, George. 1947. "The 'Marshall Plan' Speech at Harvard University," 5 Jun 1947. Text at http://www.oecd.org/document/10/0,3343,en_2649_201185_1876938_1_1_1_1,00.html

Miller, James. 1983. "Taking Off the Gloves: The United States and the Italian Election of 1948." Diplomatic History 7(1): 35-56.

Moore, Mick. (1998) "Death without Taxes: Democracy, State Capacity, and Aid Dependence in the Fourth World." In The Democratic Developmental State: Politics and Institutional Design, ed. Mark Robinson and Gordon White. Oxford: Oxford University Press.

Morgenthau, Hans. 1962. "A Political Theory of Foreign Aid." American Political Science Review. 56 (2): 301-309.

Moyo, Dambisa. 2009. Dead Aid: Why aid is not working and how there is another way for Africa. New York: Penguin.

Nancy, Gilles, and Boriana Yontcheva. 2006. "Does NGO Aid Go to the Poor? Empirical Evidence from Europe." IMF Working Paper No. 06/39.

Nelson, Stephen. 2009. Creating Credibility: The International Monetary Fund and the Neoliberal Revolution in the Developing World. Ph.D. dissertation, Department of Government, Cornell University.

Neumayer, Eric. 2003. "What Factors Determine the Allocation of Aid by Arab Countries and Multilateral Agencies?” Journal of Development Studies, 39 (4): 134-147.

New York Times. 2010. "President Karzai Lashes Out." Editorial: April 3, p. A16.

Nichol, Jim. 2009. "Kyrgyzstan: Recent Developments and U.S. Interests." Congressional Research Service: Aug 9.

North, Douglass C. and Barry R. Weingast. (1989) "Constitutions and Commitment: The Evolution of Institutions Governing Public Choice in Seventeenth-Century England." Journal of Economic History. 49 (4) (December), 803-832.

Nunnenkamp, Peter, Janina Weingarth, and Johannes Weisser. 2009. "Is NGO Aid Not So Different After All? Comparing the Allocation of Swiss Aid by Private and Official Donors." European Journal of Political Economy. 25 (4): 422-438.

Perlez, Jane. 1990. "U.S. Bars New Aid in a Sudan Famine.” New York Times. Oct 5.

Peterson, S. 2000. Me Against My Brother. New York: Routledge

Phillips, Michael. 2006. "Controlling Carrots and Sticks: White House Tries to Rein in Foreign-Aid Agency it Recently Created.” Wall Street Journal. Jun 30.

Rajan, Raghuram and Arvind Subramanian. 2011. "Aid, Dutch Disease, and Manufacturing Growth." Journal of Development Economics, 94 (1): 106-118.

Richard, Anne and George Rupp. 2009. “The 'DFID Model': Lessons for the U.S.” The Wave: Currents in Transatlantic Policy. February.

Rodrik, Dani. 2008. "The Real Exchange Rate and Economic Growth." Brookings Papers on Economic Activity. 2008: 2.

Roodman, David. 2007. "Macro Aid Effectiveness Research: A Guide for the Perplexed." Center for Global Development. Working Paper No 134.

Ruttan, Vernon W., 1996, United States Development Assistance Policy: The Domestic Politics of Foreign Economic Aid, The Johns Hopkins University Press, Baltimore. 
Schrader, Peter, Steven Hook, and Bruce Taylor. 1998. "Clarifying the Foreign Aid Puzzle: A

Comparison of American, Japanese, French, and Swedish Aid Flows." World Politics. 50 (2): 294-323.

Svensson, Jakob. (2000) "Foreign aid and rent-seeking." Journal of International Economics. 51 (2), August 2000, 437-461.

Tavares, José. 2003. “Does Foreign Aid Corrupt?” Economics Letters 79: 99-106.

Thomson, Brian. 2007. "Sierra Leone: Reform or Relapse? Conflict and Government Reform." Chatham House, UK.

Tilly, Charles. (1992) Coercion, Capital and European States, AD 990-1992. Cambridge, MA:

Blackwell.

Tornell, Aaron and Philip R. Lane. (1999) “The Voracity Effect.” American Economic Review. 89 (1), March 1999, 22-46.

Transparency International. 2004. Global Corruption Report 2004. Berlin: www.transparency.org. USAID. 2000. "Decentralization and Democratic Local Governance Programming Handbook." US Agency for International Development: Center for Democracy and Governance.

Uvin, Peter. (1998) Aiding Violence: The Development Enterprise in Rwanda. West Hartford, CT: Kumarian Press.

Walsh, Nick. 2005. "Uzbekistan kicks US out of military base." The Guardian. Aug 1.

Werker, Eric and Faisal Ahmed. 2008. "What do Non-Governmental Organizations Do?” Journal of Economic Perspectives. 22 (2): 73-92.

World Bank. 2005. Conditionality Revisited: Concepts, Experiences, and Lessons. Edited by Stefan Koeberle, Peter Silarszky, and Gero Verheyen.

Woods, Ngaire, 2003, The United States and the International Financial Institutions: Power and Influence within the World Bank and the IMF, in: Foot, McFarlane and Mastanduno (Eds.), US Hegemony and International Organizations, Oxford: 92-114.

Zhang, Guang. 2004. "The Determinants of Foreign Aid Allocation across China: The Case of World Bank Loans.” Asian Survey 44(5): 691-710. 